\title{
Hałas lotniczy \\ jako efekt funkcjonowania infrastruktury lotniskowej
}

\section{Wstęp}

Zagrożenia dla życia i zdrowia ludzkiego, jak również dla środowiska naturalnego przybierają różnorodną formę. Jedną z nich jest hałas, który oprócz wymienionych już negatywnych skutków wywiera niekorzystne następstwa ekonomiczne, jak np. obniżenie wartości nieruchomości znajdujących się w pobliżu jego oddziaływania. Jak podkreśla Ł. Dubiński „tak szerokie spektrum oddziaływania hałasu powoduje, że stanowi on przedmiot regulacji należących do różnych dziedzin prawa, w tym przede wszystkim prawa ochrony środowiska"1. Wskazać należy, że prawna ochrona środowiska przed hałasem związanym z eksploatacją lotnisk doczekała się w doktrynie opracowań, które odnoszą się do jego podstawowego źródła, czyli statków powietrznych ${ }^{2}$. Jednak niniejsze rozważania mają na celu przybliżenie zagadnienia możliwości wprowadzania ograniczeń i zakazów w celu zmniejszenia hałasu generowanego na lotniskach, poprzez wydanie decyzji wprowadzającej ograniczenia operacyjne w porcie

1 Szerzej zob.: Ł. Dubiński, Prawne aspekty ochrony środowiska przed hałasem związanym z eksploatacja lotniska, w: Działalność lotnicza w Polsce, red. K. Biskup, Z. Bukowski, Wydawnictwo UKW, Bydgoszcz 2015, s. 121; K. Biskup, Spadek wartości nieruchomości wokót infrastruktury lotniskowej, w: Prawne, administracyjne i ekonomiczne uwarunkowania działalności lotniczej w Polsce, red. Z. Bukowski, K. Biskup, Wydawnictwo UKW, Bydgoszcz 2014, s. $125-134$.

2 Ł. Dubiński, Prawne aspekty ochrony środowiska przed hałasem zwiazanym z eksploatacją lotniska, w: Działalność lotnicza w Polsce..., s. 121-133. 
lotniczym, a więc podkreślenie konsekwencji, jakie wiążą się z ewentualnym przekroczeniem norm emisji hałasu.

\section{Normy dotyczące hałasu a obowiązki zarządzającego lotniskiem}

Podstawowym aktem prawnym, który reguluje kwestie związane z przeciwdziałaniem hałasowi, jest ustawa z dnia 27 kwietnia 2001 r. - Prawo ochrony środowiska ${ }^{3}$. Zgodnie $\mathrm{z}$ art. 3 pkt 5) pr.o.ś. hałas to dźwięk o częstotliwości od $16 \mathrm{~Hz}$ do $16000 \mathrm{~Hz}$. Natomiast w wyroku z dnia 25 kwietnia 2018 r. Sąd Okręgowy w Olsztynie podkreślił, że ,z treści rozporządzenia Ministra Środowiska z dnia 14 czerwca 2007 r. w sprawie dopuszczalnych poziomów hałasu w środowisku, zmienionego rozporządzeniem Ministra Środowiska z dnia 1 października 2012 (tabela 1) wynika z kolei, że granica dopuszczalnego poziomu hałasu powodowanego przez poszczególne grupy źródeł hałasu za wyjątkiem hałasu powodowanego przez starty, lądowania i przeloty statków powietrznych oraz linie elektroenergetyczne w czasie dnia na terenach zabudowy mieszkaniowej wielorodzinnej i zamieszkania wielorodzinnego, terenach zabudowy zagrodowej oraz terenach usługowo-mieszkaniowych (pkt. 3), a także na terenach w strefach śródmiejskich miastach powyżej 100 tys. mieszkańców (pkt. 4), wynosi $55 \mathrm{~dB}$ "4.

Mając na względzie fakt, że hałas jest uciążliwością emitowaną do środowiska, ustawodawca zdecydował się na reglamentowanie tego zagadnienia przepisami ustawy. Za K. Gruszeckim ${ }^{5}$ przyjąć należy, że rozwiązania zawarte w pr.o.ś. mają zagwarantować życie w godnych warunkach, co w konsekwencji realizuje postanowienia art. 8 ust. 1 Konwencji o ochronie praw człowieka i podstawowych wolności sporządzonej w Rzymie 4 listopada 1950 r. ${ }^{6}$. Zgodnie z przywołanym przepisem: „Każdy ma prawo do poszanowania swojego życia prywatnego i rodzinnego, swojego mieszkania i swojej korespondencji”. I tak, w wyroku z dnia 22 listopada 2011 r. Europejskiego Trybunału Praw Człowieka ${ }^{7}$ wprost podkreślono, że: „Naruszenia prawa do poszanowania mieszkania nie ograniczają się do konkretnych naruszeń, takich jak wtargnięcie do mieszkania

3 T.j. Dz.U. 2020, poz. 1219 ze zm., dalej: pr.o.ś.

${ }^{4}$ Wyrok SO w Olsztynie z dnia 25 kwietnia 2018 r., sygn. akt VII Ka 360/18, zbiór orzeczeń LEX nr 2505869.

${ }^{5}$ K. Gruszecki, art. 112, w: K. Gruszecki, Prawo ochrony środowiska, wyd. 5, System Informacji Prawnej LEX 2019 (wersja elektroniczna).

6 Dz.U. 1993, nr 61, poz. 284 ze zm.

${ }^{7}$ Wyrok ETPC z 22 listopada 2011 r., sygn. 24202/10, ZAMMIT MAEMPEL v. MALTA, zbiór orzeczeń LEX nr 1056543. 
danej osoby, lecz mogą także obejmować naruszenia, które się rozprzestrzeniają, takie jak hałas, emisje, wonie lub inne podobne formy ingerencji. Poważne naruszenie może skutkować naruszeniem prawa osoby do poszanowania jej mieszkania, jeżeli uniemożliwia tej osobie korzystanie z udogodnień swego mieszkania. [...] Artykuł 8 Konwencji znajduje w szczególności zastosowanie do poważnych zanieczyszczeń środowiska naturalnego, które mogą wpływać na dobrostan jednostek i uniemożliwiać im korzystanie ze swych mieszkań w taki sposób, że wpływa to ujemnie na ich życie prywatne i rodzinne, nawet wówczas, gdy nie występuje poważne zagrożenie dla ich zdrowia"8.

$\mathrm{Z}$ powyższego wynika, że życie człowieka w środowisku wolnym od uciążliwości hałasowych ma kluczowe znaczenie. Zatem ochrona praw człowieka powinna również polegać na zagwarantowaniu możliwości korzystania z udogodnień swojego mieszkania, bez poważnych naruszeń poziomu hałasu emisyjnego, w tym pochodzącego z lotnisk.

Podstawowymi sposobami ochrony przed hałasem są działania polegające na zapewnieniu jak najlepszego stanu akustycznego środowiska, do których należy zaliczyć w szczególności utrzymanie poziomu hałasu poniżej dopuszczalnego lub co najmniej na tym poziomie, jak i zmniejszenie poziomu hałasu co najmniej do dopuszczalnego, gdy nie jest on dotrzymany (art. 112 pr.o.ś.). Działania, o których mowa powyżej, winny być uwzględniane w procesie wydawania aktów administracyjnych, stanowiących podstawę korzystania ze środowiska, czy w procedurze planistycznej związanej z tworzeniem aktów prawa miejscowego?.

Podkreślenia wymaga, że ustawodawca, posługując się w art. 112 pr.o.ś. sformułowaniem „co najmniej”, pozostawił możliwość dalszego ograniczania poziomu hałasu, jeżeli czynności zmierzające do osiągnięcia najlepszego stanu środowiska by ku temu prowadziły. Niemniej jednak ich realizacja nie może „naruszać obowiązujących reguł ogólnych - w tym wynikających z zasady zrównoważonego rozwoju oraz zasad związanych z wolnością gospodarowania czy ochroną własności"10.

Dopuszczalne poziomy hałasu $\mathrm{w}$ środowisku określane są, zgodnie $\mathrm{z}$ art. 113 pr.o.ś., w rozporządzeniu ministra właściwego do spraw klimatu, wydawanym w porozumieniu z ministrem właściwym do spraw zdrowia. Delegacja ustawowa zawarta w ust. 1 art. 113 pr.o.ś. wskazuje, że dopuszczalne poziomy hałasu w środowisku zostaną określone w rzeczonym rozporządzeniu w związ$\mathrm{ku} \mathrm{z}$ potrzebą zapewnienia należytej ochrony środowiska przed hałasem oraz mając na uwadze przepisy prawa Unii Europejskiej odnoszące się do oceny i zarządzania poziomem hałasu w środowisku. Aktualne rozporządzenie, o którym

\footnotetext{
${ }^{8}$ K. Gruszecki, art. 112, w: K. Gruszecki, Prawo ochrony środowiska...

${ }^{9}$ K. Gruszecki, art. 112, w: K. Gruszecki, Prawo ochrony środowiska...

${ }^{10}$ Wyrok NSA z dnia 25 kwietnia 2017 r., sygn. akt II OSK 2156/15, zbiór orzeczeń LEX
} nr 2305422 
mowa w omawianym przepisie, to rozporządzenie Ministra Środowiska z dnia 14 czerwca 2007 r. w sprawie dopuszczalnych poziomów hałasu w środowisku ${ }^{11}$. Akt ten wskazuje przede wszystkim na zróżnicowane dopuszczalne poziomy hałasu dla poszczególnych rodzajów terenów faktycznie zagospodarowanych, jak również dopuszczalne poziomy hałasu z uwzględnieniem rodzaju obiektu lub działalności będącej źródłem hałasu oraz okresy, do których odnoszą się poziomy hałasu, jako czas odniesienia (zgodnie z art. 113 ust. 2 pr.o.ś.). Ustawodawca przewidział możliwość ustalenia w rozporządzeniu wykonawczym poziomy hałasu z uwzględnieniem zmienności działania jego źródeł w czasie, charakterystyki jego częstotliwości czy zawartości impulsów akustycznych. W konsekwencji dopuszczalne poziomy hałasu w środowisku zostały określone w załączniku do rozporządzenia, który zawiera tabelaryczne zestawienie dopuszczalnych poziomów hałasu w środowisku, wyróżniono:

1. Dopuszczalne poziomy hałasu w środowisku powodowanego przez poszczególne grupy źródeł hałasu, z wyłączeniem hałasu powodowanego przez starty, lądowania i przeloty statków powietrznych oraz linie elektroenergetyczne, wyrażone wskaźnikami LAeq D i LAeq N, które to wskaźniki mają zastosowanie do ustalania i kontroli warunków korzystania ze środowiska, w odniesieniu do jednej doby.

2. Dopuszczalne poziomy hałasu w środowisku powodowanego przez starty, lądowania i przeloty statków powietrznych oraz linie elektroenergetyczne, wyrażone wskaźnikami LAeq D i LAeq N, które to wskaźniki mają zastosowanie do ustalania i kontroli warunków korzystania ze środowiska, w odniesieniu do jednej doby.

3. Dopuszczalne poziomy hałasu w środowisku powodowanego przez poszczególne grupy źródeł hałasu, z wyłączeniem hałasu powodowanego przez starty, lądowania i przeloty statków powietrznych oraz linie elektroenergetyczne, wyrażone wskaźnikami LDWN i LN, które to wskaźniki mają zastosowanie do prowadzenia długookresowej polityki w zakresie ochrony przed hałasem.

4. Dopuszczalne poziomy hałasu w środowisku powodowanego przez starty, lądowania i przeloty statków powietrznych oraz linie elektroenergetyczne wyrażone wskaźnikami LDWN i LN, które to wskaźniki mają zastosowanie do prowadzenia długookresowej polityki w zakresie ochrony przed hałasem. Jak słusznie przyjmuje Ł. Dubiński, niezależnie od granic dopuszczalnego hałasu przyjętych w omawianym rozporządzeniu, zarządzający lotniskami są związani normami, jakie wynikają z zasad prawa ochrony środowiska, przy założeniu, że nie powinny one służyć korygowaniu przyjętych w akcie wykonawczym wytycznych ${ }^{12}$. Powyższe wiąże się przede wszystkim z tym, że zasięg

11 T.j. Dz.U. 2014, poz. 112.

12 Ł. Dubiński, Prawne aspekty ochrony środowiska przed hałasem związanym z eksploatacją lotniska, w: Działalność lotnicza w Polsce..., s. 132. 
oraz kierunek rozprzestrzeniania się hałasu lotniczego jest szeroki i zależy od szeregu czynników, do których w literaturze przedmiotu zaliczono ${ }^{13}$ : stan atmosfery otaczającej źródło hałasu, temperaturę i wiatr, ukształtowanie i zagospodarowanie terenu czy pory dnia.

Zatem, rozległe oddziaływanie emisji z lotniska jest podstawową przesłanką, która przemawia za wprowadzaniem ograniczeń w jego funkcjonowaniu w przypadku przekroczenia standardów jakości środowiska.

Mając na względzie powyższe, ustawodawca w art. 174 ust. 1 pr.o.ś. wskazuje, że eksploatacja lotnisk nie może powodować przekroczenia standardów jakości środowiska, a co za tym idzie emisje polegające na powodowaniu hałasu, powstające w związku z eksploatacją lotniska, nie mogą spowodować przekroczenia standardów jakości środowiska poza terenem, do którego zarządzający tym obiektem ma tytuł prawny. Jako wyjątek traktować należy sytuację, w której, w związku z eksploatacją lotniska utworzono obszar ograniczonego użytkowania (dalej: OOU). Wówczas eksploatacja nie może spowodować przekroczenia standardów jakości środowiska poza tym obszarem. Przesłanki utworzenia OOU ${ }^{14}$ określa art. 135 ust. 1 pr.o.ś., w którym w wskazano, że w przypadku gdy z przeglądu ekologicznego albo z oceny oddziaływania przedsięwzięcia na środowisko wymaganej przez przepisy ustawy z dnia 3 października 2008 r. o udostępnianiu informacji o środowisku i jego ochronie, udziale społeczeństwa $\mathrm{w}$ ochronie środowiska oraz o ocenach oddziaływania na środowisko ${ }^{15}$, albo z analizy porealizacyjnej wynika, iż pomimo zastosowania dostępnych rozwiązań technicznych, technologicznych i organizacyjnych nie mogą być dotrzymane standardy jakości środowiska poza terenem danego lotniska, tworzy się OOU. Podkreślenia wymaga, że z treści art. 135 ust. 1 wynika, iż OOU może być utworzony tylko dla enumeratywnie wymienionych w nim instalacji, służących do prowadzenia działalności mających cechy użyteczności publicznej. Do kategorii instalacji, o których mowa $\mathrm{w}$ art 135 ust. 1 , zaliczyć należy lotniska ${ }^{16}$.

13 B. Rzeczyński, Komunikacja lotnicza w planowaniu przestrzennym, Politechnika Poznańska, Poznań 1996, s. 43—44 za S. Zajas, D. Ozga, Lotnictwo a środowisko naturalne, Akademia Obrony Narodowej, Warszawa 2011, s. 22.

14 Szerzej na temat obszarów ograniczonego użytkowania wokół lotnisk zob.: K. Biskup, Spadek wartości nieruchomości wokól infrastruktury lotniskowej, w: Prawne, administracyjne i ekonomiczne uwarunkowania działalności lotniczej w Polsce, red. K. Biskup, Z. Bukowski, Wydawnictwo UKW, Bydgoszcz 2014, s. 125-134; A. Folgier, Warunki tworzenia obszarów ograniczonego użytkowania wokól infrastruktury lotniczej, w: Prawne, administracyjne $i$ ekonomiczne uwarunkowania działalności lotniczej w Polsce, red. K. Biskup, Z. Bukowski, Wydawnictwo UKW, Bydgoszcz 2014, s. 101-112.

15 T.j. Dz.U. 2020, poz. 283.

16 Wyrok NSA z dnia 11 września 2019 r., sygn. akt II OSK 2520/17, zbiór orzeczeń LEX nr 2739729. 
Kolejnym instrumentem wprowadzonym przez ustawodawcę w pr.o.ś. jest, oprócz zachowania standardów ochrony środowiska, zobowiązanie zarządzającego lotniskiem do dokonywania pomiarów poziomu hałasu w środowisku w związku z eksploatacją infrastruktury lotniskowej (art. 175 pr.o.ś.). Wymagania w tym zakresie określa akt wykonawczy wydany na podstawie art. 176 ust. 1 pr.o.ś., tj. rozporządzenie Ministra Środowiska z dnia 16 czerwca 2011 r. w sprawie wymagań w zakresie prowadzenia pomiarów poziomów substancji lub energii w środowisku przez zarządzającego drogą, linią kolejową, linią tramwajową, lotniskiem lub portem ${ }^{17}$. Zgodnie z $\S 2$, wskazanego powyżej aktu prawnego, należy prowadzić ciągłe pomiary poziomów energii środowisku dla wyznaczenia wartości poziomów hałasu w środowisku w związku z eksploatacją:

1. Lotnisk, na których ma miejsce łącznie ponad 50 tys. startów, lądowań i przelotów statków powietrznych w roku kalendarzowym, niezależnie od położenia lotniska.

2. Lotnisk, na których ma miejsce łącznie ponad 10 tys. startów, lądowań i przelotów statków powietrznych w roku kalendarzowym, położonych na terenie aglomeracji lub mających trasy dolotu i odlotu nad obszarami aglomeracji.

Oprócz powyższego, zarządzający lotniskami muszą pamiętać o okresowych pomiarach poziomów substancji lub energii w środowisku dla wyznaczenia poziomów hałasu w środowisku, obejmujących okres co najmniej jednej doby, wprowadzonych w związku z eksploatacją lotnisk, na których ma miejsce łącznie ponad 5 tys. startów, lądowań i przelotów statków powietrznych w roku kalendarzowym, niezależnie od położenia lotniska. Okresowe pomiary poziomów hałasu, przeprowadza się co 5 lat ( $\$ 3$ ust. 1 pkt d) w zw. z $\S 3$ ust. 2 rozporządzenia).

Niemniej jednak, za Ł. Dubińskim, podkreślić należy, że oprócz wskazanych powyżej obowiązków na zarządzających lotniskami może zostać nałożony w drodze decyzji administracyjnej obowiązek pomiarowy. Do takiej sytuacji dojdzie w sytuacji, w której mamy do czynienia z przekroczeniem dopuszczalnego poziomu substancji w powietrzu, w odniesieniu do zakładów, gdzie jest eksploatowana instalacja, zakwalifikowana jako przedsięwzięcie mogące znacząco oddziaływać na środowisko w rozumieniu ustawy z dnia 3 października 2008 r. o udostępnianiu informacji o środowisku i jego ochronie, udziale społeczeństwa w ochronie środowiska oraz ocenach oddziaływania na środowisko. Zgodnie z art. 95 ust. 1 pr.o.ś. organem właściwym do wydania decyzji jest marszałek województwa ${ }^{18}$. Ustawodawca określił czas, w którym podmiot zobowiązany do przeprowadzenia pomiarów zobowiązany jest do ich przechowania. Zgodnie z art. 95 ust. 2 pr.o.ś. okres ten to 5 lat od zakończenia roku kalendarzowego, którego dotyczą pomiary ${ }^{19}$.

17 Dz.U. 2011, nr 140, poz. 824.

18 Ł. Dubiński, Prawne aspekty ochrony środowiska przed hałasem zwiąanym z eksploatacją lotniska, w: Działalność lotnicza w Polsce..., s. 130.

19 B. Rakoczy, art. 95, w: Z. Bukowski, E.K. Czech, K. Karpus, B. Rakoczy, Prawo ochrony 
Ponadto, ustawodawca w art. 178 pr.o.ś. wprowadził możliwość wydania decyzji przez organ ochrony środowiska nakładającej na zarządzającego lotniskiem obowiązek prowadzenia $\mathrm{w}$ określonym czasie pomiarów poziomów substancji lub energii w środowisku w związku z jego eksploatacją, które wykraczają m.in. poza obowiązki, o których mowa w art. 175 ust. 1-3, jeżeli przeprowadzone kontrole poziomów substancji bądź energii w środowisku dowodzą przekraczania standardów jakości środowiska. Przekroczenie standardów, o których mowa powyżej, musi wynikać z eksploatacji lotniska.

Wprowadzone w pr.o.ś. instrumenty służące przeciwdziałaniu hałasowi, to ogólne reguły, jakie obwiązują na terytorium Rzeczypospolitej Polskiej, a odnoszą się do emisji hałasu przez wskazane zakłady, w tym lotniska. Szczegółowe regulacje stanowiące wyraz europeizacji i internacjonalizacji prawa w zakresie ograniczenia hałasu generowanego na lotniskach wprowadzono ustawą z dnia 3 lipca 2002 r. - Prawo lotnicze ${ }^{20}$.

\section{Instrumenty wprowadzone w polskim prawie lotniczym związane z ograniczeniem hałasu generowanego na lotniskach}

Ochrona środowiska naturalnego to priorytetowe zadanie, jakie przed sobą stawiają instytucje i organizacje lotnicze. Dowodem na to są podejmowane działania zmierzające do poprawy jakości środowiska naturalnego na szczeblu międzynarodowym, europejskim oraz krajowym. Do powyższych zaliczyć należy utworzenie Agencji Unii Europejskiej ds. Bezpieczeństwa Lotniczego, która jest organem właściwym m.in. w sprawie zapewnienia wysokiego, ujednoliconego poziomu ochrony środowiska poprzez certyfikację oraz nadzór nad produkcją silników lotniczych. W zakresie hałasu lotniczego wdrożono dyrektywę 2002/49/ WE Parlamentu Europejskiego i Rady z dnia 25 czerwca 2002 r. odnoszącą się do oceny i zarządzania poziomem hałasu w środowisku

Ustawodawca w u.p.l. wprowadził rozwiązania, które ukierunkowane są m.in. na ograniczenie hałasu generowanego przez infrastrukturę lotniskową. I tak, ograniczenie ruchu na lotnisku czy zamknięcie go dla ruchu lotniczego na czas oznaczony może nastąpić w drodze decyzji wydanej przez Prezesa Urzędu Lotnictwa Cywilnego (dalej: Prezes ULC) w przypadku niespełniania przez lotnisko wymagań technicznych lub eksploatacyjnych określonych na podstawie u.p.l. Jeśli lotnisko pomimo upływu terminu nadal nie spełnia wymaganych prawem wymagań, wskazany organ może w drodze aktu administracyjnego

środowiska. Komentarz, System Informacji Prawnej LEX 2013 (wersja elektroniczna).

${ }^{20}$ T.j. Dz.U. 2020, poz. 1970 ze zm., dalej: u.p.l. 
wykreślić lotnisko z rejestru (art. 71 u.p.l.). Zatem Prezes ULC, realizując swoje obowiązki związane $\mathrm{z}$ nadzorowaniem oraz kontrolowaniem przestrzegania przepisów prawnych w zakresie lotnictwa cywilnego i lotniczej działalności gospodarczej, został wyposażony w kompetencje, które pozwalają ograniczyć ruch na lotnisku, a w sytuacjach szczególnych zamknąć, a nawet wykreślić lotnisko z rejestru. Dodatkowo, w ramach art. 71a-71e u.p.l., ustawodawca umożliwił Prezesowi ULC podejmowanie działań, które będą ukierunkowanie na ograniczenie hałasu generowanego na lotniskach ${ }^{21}$.

Prezes ULC, na wniosek zarządzającego lotniskiem bądź na wniosek wojewody właściwego miejscowo dla portu lotniczego, w którym wykonuje się ponad 50000 operacji cywilnych statków powietrznych w roku kalendarzowym, obliczanych na podstawie średniej liczby operacji w ostatnich 3 latach kalendarzowych poprzedzających ocenę hałasu ${ }^{22}$, może w drodze decyzji administracyjnej wprowadzić w porcie lotniczym ograniczenia operacyjne. Przez powyższe rozumieć należy takie działania związane $\mathrm{z}$ hałasem, które ograniczają dostępność lub przepustowość portu lotniczego, w tym ograniczenia operacyjne mające na celu wycofanie $\mathrm{z}$ eksploatacji w poszczególnych portach lotniczych statków powietrznych marginalnie zgodnych, jak również ograniczenia operacyjne o charakterze częściowym mające na przykład zastosowanie przez określony czas w ciągu dnia lub wyłącznie w odniesieniu do niektórych dróg startowych portu lotniczego ${ }^{23}$. Tak zredagowane przepisy u.p.l. wynikają z wdrażania do porządku prawnego Rzeczpospolitej Polskiej przepisów europejskich, w tym rozporządzenia Parlamentu Europejskiego i Rady 2014/598/UE z dnia 16 kwietnia 2014 r. w sprawie ustanowienia zasad i procedur w odniesieniu do wprowadzenia ograniczeń operacyjnych odnoszących się do poziomu hałasu w portach lotniczych Unii w ramach zrównoważonego podejścia oraz uchylające dyrektywę 2002/30/WE (dalej: rozporządzenie 2014/598/UE).

Tryb podejmowania decyzji związanej $\mathrm{z}$ ograniczeniem bądź zakazem wykorzystywania lotniska przez samoloty marginalnie zgodne określono $\mathrm{w}$ art. $71 \mathrm{~b}$ u.p.l. Zgodnie z wskazanym powyżej przepisem Prezes ULC wydaje decyzję po uzgodnieniu jej z wojewodą właściwym miejscowo ze względu

${ }^{21}$ K. Marut, art. 71a, w: Prawo lotnicze. Komentarz, red. M. Żylicz, Wolters Kluwer Polska, Warszawa 2016, s. 284.

${ }_{22}$ Art. 2 pkt 2) rozporządzenia Parlamentu Europejskiego i Rady 2014/598/UE z dnia 16 kwietnia 2014 r. w sprawie ustanowienia zasad i procedur w odniesieniu do wprowadzenia ograniczeń operacyjnych odnoszących się do poziomu hałasu w portach lotniczych Unii w ramach zrównoważonego podejścia oraz uchylające dyrektywę 2002/30/WE (Dz.Urz. UE L 173/65 z dnia 12 kwietnia 2014 r.).

${ }^{23}$ Art. 2 pkt 6) rozporządzenia Parlamentu Europejskiego i Rady 2014/598/UE z dnia 16 kwietnia 2014 r. w sprawie ustanowienia zasad i procedur w odniesieniu do wprowadzenia ograniczeń operacyjnych odnoszących się do poziomu hałasu w portach lotniczych Unii w ramach zrównoważonego podejścia oraz uchylające dyrektywę 2002/30/WE (Dz.Urz. UE L 173/65 z dnia 12 kwietnia 2014 r.). 
na położenie portu lotniczego oraz po przeprowadzeniu przez zarządzającego tym portem lotniczym konsultacji, o których mowa w art. 6 ust. 2 pkt d) rozporządzenia 2014/598/UE. W przypadku decyzji negatywnej, zarządzającemu lotniskiem służy prawo odwołania do ministra właściwego do spraw transportu. Kolejne artykuły, tj. art. 71c-71e, określają m.in.:

1. Obowiązek publikacji przez Prezesa ULC informacji o wprowadzonych ograniczeniach w celu ograniczenia hałasu generowanego na lotniskach;

2. Możliwość wydania zwolnienia dotyczącego operacji lotniczych statków powietrznych marginalnie zgodnych, o których mowa w art. 9 oraz art. 10 rozporządzenia 2014/598/UE;

3. Delegację ustawową dla ministra właściwego transportu do wydania rozporządzenia w sprawie zwolnień z ograniczeń operacyjnych ${ }^{24}$.

Wskazane powyżej rozwiązania to nie jedyne działania podjęte w celu ochrony środowiska naturalnego. Wspomnieć należy, że już od 2009 r. ACI EUROPE (ang. Airports Council International Europe) zainicjowała program akredytacji w zakresie emisji CO2 na lotniskach, tj. Airport Carbon Acreditation $^{25}$. Powyższe działania zarówno na szczeblu krajowym, jak i europejskim czy międzynarodowym, potwierdzają, jak ważne jest działanie dla zachowania środowiska naturalnego w stanie niepogorszonym.

\section{Podsumowanie}

Poczynione rozważania prowadzą do następujących wniosków. W pierwszej kolejności należy podkreślić, że mamy do czynienia z dychotomicznym uregulowaniem instrumentów, jakie służą przeciwdziałaniu hałasowi. Jedne, określone w sposób kompleksowy w pr.o.ś., które pozwalają na stałe monitorowanie poziomu hałasu emitowanego przez lotniska, a co za tym idzie infrastrukturę lotniskową. Kolejne, uregulowane w u.p.l., które co do zasady ocenić należy jako rozwiązania liberalne, tj. takie, które nie będą wywierały negatywnego wpływu na rozwój i eksploatację lotniska.

Decyzja, o której mowa w art. 71a ust. 1 u.p.l., ma charakter decyzji uznaniowej, ustawodawca konstruując bowiem przepis, posłużył się sformułowaniem „może”. Zatem Prezes ULC może w drodze decyzji administracyjnej wprowadzić w porcie lotniczym ograniczenia operacyjne w celu ograniczenia hałasu

${ }^{24}$ Rozporządzenie Ministra Infrastruktury z dnia 16 września 2019 r. w sprawie zwolnień z ograniczeń operacyjnych (Dz.U. 2019, poz. 1875).

${ }^{25}$ Zob. więcej: K. Biskup, „Ekologiczne lotniska”- regulacje prawne w przedmiocie funkcjonowania prośrodowiskowej infrastruktury lotniczej, „Problemy Transportu i Logistyki” 2017, nr 4, s. 9-17. 
generowanego na lotniskach. Działania przez niego podejmowane w związku z powyższą procedurą muszą być zgodne z rozporządzeniem 2014/598/UE.

\section{Literatura}

Biskup K., Spadek wartości nieruchomości wokót infrastruktury lotniskowej, w: Prawne, administracyjne i ekonomiczne uwarunkowania działalności lotniczej w Polsce, red. Z. Bukowski, K. Biskup, Wydawnictwo UKW, Bydgoszcz 2014, s. 125-134.

Biskup K., 2017, „Ekologiczne lotniska” - regulacje prawne w przedmiocie funkcjonowania prośrodowiskowej infrastruktury lotniczej, „Problemy Transportu i Logistyki” 2017, nr 4, s. $9-17$.

Dubiński Ł., Prawne aspekty ochrony środowiska przed hałasem zwiazanym z eksploatacja lotniska, w: Działalność lotnicza w Polsce, red. K. Biskup, Z. Bukowski, Wydawnictwo UKW, Bydgoszcz 2015, s. 121-133.

Folgier A., Warunki tworzenia obszarów ograniczonego użytkowania wokót infrastruktury lotniczej, w: Prawne, administracyjne i ekonomiczne uwarunkowania działalności lotniczej $w$ Polsce, red. K. Biskup, Z. Bukowski, Wydawnictwo UKW, Bydgoszcz 2014, s. 101-112.

K. Gruszecki, Prawo ochrony środowiska, wyd. 5, System Informacji Prawnej LEX 2019 (wersja elektroniczna).

Prawo lotnicze. Komentarz, red. M. Żylicz, Wolters Kluwer Polska, Warszawa 2016.

Z. Bukowski, E.K. Czech, K. Karpus, B. Rakoczy, Prawo ochrony środowiska. Komentarz, System Informacji Prawnej LEX 2013 (wersja elektroniczna).

Rzeczyński B., Komunikacja lotnicza w planowaniu przestrzennym, Politechnika Poznańska, Poznań 1996.

Zajas S., Ozga D., Lotnictwo a środowisko naturalne, Akademia Obrony Narodowej, Warszawa 2011.

Orzecznictwo

Wyrok ETPC z 22 listopada 2011 r., sygn. akt 24202/10, ZAMMIT MAEMPEL v. MALTA, zbiór orzeczeń LEX nr 1056543.

Wyrok Naczelnego Sądu Administracyjnego z dnia 25 kwietnia 2017 r. sygn. akt II OSK 2156/15, zbiór orzeczeń LEX nr 2305422.

Wyrok Naczelnego Sądu Administracyjnego z dnia 11 września 2019 r., sygn. akt II OSK 2520/17, zbiór orzeczeń LEX nr 2739729.

Wyrok Sądu Okręgowego w Olsztynie z dnia 25 kwietnia 2018 r., sygn. akt VII Ka 360/18, zbiór orzeczeń LEX nr 2505869. 
Katarzyna Biskup-Grabowska

\section{Aviation noise as a result of the functioning of the airport infrastructure}

\section{Summary}

The development of civil aviation, and hence the increased use of airport infrastructure, leads to the exceeding of environmental noise standards. The subject of this article is to present the issues related to the possibility of introducing restrictions and bans to reduce noise generated at airports.

Key words: aviation noise, administrative decision, environmental protection Катажина Бискуп-Грабовска

\section{Авиационный шум как результат функционирования инфраструктуры аэропорта}

Резюме

Гражданской авиации и, следовательно, более широкое использование инфраструктуры аэропорта приводит к превышению допустимого уровня шума в окружающей среде. Темой данной статьи является изучение вопросов, связанных с возможностью введения ограничений и запретов с целью снижения шума, производимого в аэропортах.

Ключевые слова: авиационный шум, административное решение, охрана окружающей среды

Katarzyna Biskup-Grabowska

\section{II rumore del traffico aereo come effetto del funzionamento delle infrastrutture aeroportuali}

\section{Sommario}

Lo sviluppo dell'aviazione civile, e quindi l'aumento dell'uso delle infrastrutture aeroportuali, porta a superare gli standard del rumore ambientale. L'oggetto di quest'articolo è quello di avvicinare le questioni relative alla possibilità di introdurre restrizioni e divieti per ridurre il rumore generato negli aeroporti.

Parole chiave: rumore aereo, decisione amministrativa, protezione dell'ambiente 